\title{
DETERMINAN KEJADIAN DIARE PADA ANAK BALITA DI KELURAHAN BAGAN DELI WILAYAH KERJA PUSKESMAS BELAWAN MEDAN
}

\author{
Putranto Manalu*, Wulan Indah Damanik, Putri Yunita Pane, Eva Ellya Sibagariang \\ Fakultas Kesehatan Masyarakat Universitas Prima Indonesia \\ *(putrantomanalu@unprimdn.ac.id)
}

\begin{abstract}
ABSTRAK
Menurut data dari WHO tahun 2013, diare masih menjadi penyebab kematian terbesar kedua pada balita. Tiap tahunnya diare menyebabkan kematian pada 760.000 balita di seluruh dunia. Banyak factor yang menyebabkan terjadinya diare pada balita yaitu personal higiene yang tidak baik, sanitasi jamban yang tidak memenuhi syarat, sumber air yang tidak memenuhi syarat dan lain-lain. Berdasarkan data yang dimiliki Puskesmas Belawan jumlah kasus diare yang di tangani dari bulan mei sampai bulan oktober tahun 2018 adalah sebanyak 498 kasus, yang di sesuaikan dengan jumlah usia 1- 4 tahun. Penelitian ini bertujuan untuk mendeskripsikan determinan kejadian kasus diare pada balita di Kelurahan Bagan Deli Wilayah Kerja Puskesmas Belawan Medan. Populasi dalam penelitian ini adalah seluruh penderita diare pada balita di Kelurahan Bagan Deli Belawan pada tahun 2018 yang berjumlah 302 orang. Sampel diambil dengan menggunakan teknik purposive sampling dan didapatkan jumlah sampel 75 orang ibu yang memiliki anak balita. Berdasarkan uji statistik menggunakan uji chi-square terdapat hubungan yang signifikan antara personal hygiene $(p=0.000)$, sanitasi jamban $(p=0,000)$, dan sumber air $(p=0,000)$ dengan kejadian diare pada balita. Penelitian ini menyimpulkan terdapat hubungan antara personal hygiene, sanitasi jamban keluarga dan sumber air dengan kejadian diare pada balita di Kelurahan Bagan Deli Wilayah Kerja Puskesmas Belawan.
\end{abstract}

Kata Kunci: Personal hygiene, sanitasi jamban, sumber air, diare

\begin{abstract}
According to data from WHO in 2013, diarrhea is still the second largest cause of death in infants. Every year diarrhea causes death in 760,000 children under five worldwide. Many factors that cause diarrhea in infants are personal hygiene that is not good, sanitary latrines that do not meet the requirements, water sources that do not meet the requirements and others. Based on data held by Puskesmas Belawan, the number of diarrhea cases handled from May to October 2018 was 498 cases, adjusted for the age of 1-4 years. This study aims to describe the determinants of diarrhea cases in infants in the Bagan Deli Village, Puskesmas Belawan Work Area. The population in this study were all diarrhea sufferers in infants in Bagan Deli Belawan Village in 2018, amounting to 302 people. Samples were taken using a purposive sampling technique and obtained a total sample of 75 mothers who have children under five. Based on statistical tests using the chi-square test there was a significant relationship between personal hygiene $(p=$ $0,000)$, latrine sanitation $(p=0,000)$, and water sources $(p=0,000)$ with the incidence of diarrhea in infants. This study concludes that there is a relationship between personal hygiene, sanitation of family toilets and water sources with the incidence of diarrhea in children under five in Bagan Deli Village, Puskesmas Belawan.
\end{abstract}

Keywords: Personal hygiene, latrine sanitation, water sources, diarrhea

\section{PENDAHULUAN}

Menurut data dari WHO (2013), diare masih menjadi penyebab kematian terbesar kedua pada balita. Tiap tahunnya diare menyebabkan kematian pada 760.000 balita di seluruh dunia. ${ }^{1}$ WHO melaporkan bahwa penyebab utama kematian pada balita adalah diare (post neonatal) sebesar $14 \%$ dan pneumonia (post neonatal) sebesar $14 \%$ kemudian malaria $8 \%$, penyakit tidak menular (post neonatal) $4 \%$ injuri (post neonatal) $3 \%$, HIVIAIDS $2 \%$, campak $1 \%$ dan lainnya $13 \%$, dan kematian yang bayi $<1$ bulan (newborns death) 41\%. Terlihat bahwa diare sebagai salah satu penyebab utama tingginya angka kematian anak di dunia. ${ }^{2}$ Pada tahun 2018 jumlah cakupan pelayanan penderita diare balita secara nasional, cakupan penderita diare balita berada di Provinsi Nusa Tenggara Barat (75,88\%), DKI Jakarta (78,54\%) dan Kalimantan Utara $(55,00 \%)$, sedangkan provinsi dengan cakupan terendah yaitu Maluku (9,77\%), Sumatera Utara $(16,70 \%)$, dan Kepulauan Riau $(18,68 \%){ }^{3}$

Di Sumatera Utara pada tahun 2018 jumlah penderita diare balita yang dilayani yaitu sebanyak 86.442 penderita $(33.07 \%)$. Kasus 
penderita diare balita terbanyak berada di Kabupaten Toba Samosir sebanyak 3.428 penderita atau 99.39\%, dan Kabupaten Mandailing Natal sebanyak 6.124 penderita atau $70,14 \%{ }^{4}$

Beberapa faktor yang mengakibatkan terjadinya diare pada balita adalah sumber air, personal hygiene, dan ketersedian jamban keluarga. Air merupakan zat yang paling penting dalam kehidupan setelah udara. Sekitar tiga per empat bagian dari tubuh kita terdiri dari air dan tidak seorangpun dapat bertahan hidup lebih dari 4-5 hari tanpa air minum. Selain itu, air juga dipergunakan untuk memasak, mencuci, mandi dan membersihkan kotoran yang ada di sekitar rumah. Air yang cukup sama pentingnya dengan air besih, karena air yang terbatas akan memudahakan timbulnya berbagai penyakit di masyarakat. Kebutuhan air rata-rata yang diperlukan setiap orang setiap hari antara 60-120 liter di negara maju, di negara berkembang termasuk Indonesia antara 30-60 liter per hari. ${ }^{5}$ Penelitian Nurpauji dkk (2015) menunjukkan bahwa ada hubungan yang bermakna antara kualitas bakteriologis air munum dengan kejadian diare pada balita. ${ }^{6}$

Tangan seseorang yang terkontaminasi/tercemar kuman, seperti tidak mencuci tangan dengan sabun setelah buang air besar, setelah menceboki anak, atau setelah memegang sesuatu yang kotor maka bila langsung memegang makanan maka kuman akan ikut masuk ke dalam saluran pencernaan yang dapat menyebabkan terjadinya penyakit diare. ${ }^{7}$ Penelitian Linda dkk. (2017) mendapati bahwa dari 87 responden hampir seluruhnya (86\%) responden yang mempunyai personal hygiene yang baik tidak mengalami diare pada balita. Dari hasil uji statistik dengan $p$-value 0.000 $(p<0.05)$ berarti ada hubungan personal hygiene ibu dengan kejadian diare di Desa Bereng. ${ }^{8}$

Tinja dan limbah yang lain adalah limbah yang pasti dihasilkan oleh setiap rumah, oleh karena itu adalah kewajiban setiap rumah tangga untuk mengelola tinja ini sebaik-baiknya. Prinsip dasarnya menganggap tinja adalah sumber penyakit terutama penyakit saluran cerna. Karenanya harus dilokalisasi untuk diolah sehingga setelah dilepas kelingkungan sudah tidak berbahaya lagi. Pengolahan yang umum dan baik adalah dengan memanfaatkan fungsi septic tank. Studi yang dilakukan Wandansari (2013) menunjukkan ada hubungan antara pemanfaatan jamban keluarga dengan kejadian keluaga diare. $^{9}$

Berdasarkan data yang dimiliki Puskesmas Belawan, diare banyak menyerang bayi dan anak balita. Hal ini terlihat dari angka kejadian diare pada anak balita tahun 2016 yakni sebesar 250 orang anak balita yang terserang penyakit diare yang didominasi umur 1-4 tahun sebesar 157 orang. Pada tahun 2017 angka kejadian diare pada anak balita semakin meningkat hingga mencapai angka 469 orang namun pada tahun 2017 didominasi oleh anak balita yang berusaia 0 sampai <6 bulan yakni sebanyak 170 orang dan angka kejadian diare pada anak balita tahun 2018 sebesar 467 orang yang didominasi oleh anak balita berusia $\geq 6$ bulan hingga $<1$ tahun sebanyak 177 orang. Jumlah kasus diare yang ditangani dari bulan Mei sampai bulan Oktober tahun 2018 adalah sebanyak 498 kasus yang berada pada rentang usia 1sampai dengan 4 tahun. Puskesmas Belawan memiliki 6 kelurahan yaitu Belawan I, Belawan II, Belawan Bahagia, Belawan Bahari, Bagan Deli, dan Sicanang. Kelurahan Belawan I memiliki 53 kasus, Kelurahan Belawan II memiliki 57 kasus, Kelurahan Belawan Bahagia memiliki 16 kasus, Kelurahan Belawan Bahari memiliki 49 kasus, Kelurahan Bagan Deli memiliki 302 kasus, dan Kelurahan Sicanang memiliki 21 kasus.

Hasil wawancara dengan beberapa ibu yang memiliki bayi dan anak balita di wilayah kerja Puskesmas Belawan didapatkan keterangan bahwa diare biasa terjadi karena bayi dan anak balita tumbuh gigi. Adapula yang mengatakan bahwa diare adalah sakit perut, makanan yang tidak bersih dan air yang dikonsumsi mengandung bakteri. Para ibu mengatakan bahwa lingkungan yang kotor seperti berseraknya sampah di sekitar pekarangan rumah karena rumah mereka adalah rumah panggung serta banyak hewan yang berkeliaran di sana seperti anjing. Selain itu penggunaan air bersih juga masih jarang karena mengingat sumber air bersihnya yang berasal dari laut dan tidak jauh dari tempat pembuangan sampah dan limbah pabrik. Penelitian ini bertujuan untuk menganalisis faktor-faktor yang mempengaruhi penyakit diare pada balita.

\section{METODE}

Penelitian ini merupakan penelitian deskriptif analitik yang bertujuan dengan rancangan penelitian cross sectional. Penelitian dilaksanakan pada bulan Februari 2020. Populasi dalam penelitian ini adalah seluruh ibu yang 
mempunyai balita yang terkena diare di Kelurahan Bagan Deli Wilayah Kerja Puskesmas Belawan sebanyak 498 orang. Sampel diambil dengan menggunakan teknik purposive sampling dan didapatkan jumlah sampel 75 orang ibu yang memiliki anak balita.

\section{HASIL}

Pada tabel 1 dapat dilihat karakteristik responden berdasarkan umur, sebagian besar balita usia 2-2,4 tahun yaitu 22 orang $(29,3 \%)$ dan sebagian kecil balita usia 1-1,4 tahun yaitu 12 orang (16\%). Berdasarkan personal hygiene, sebagian besar responden memiliki personal hygiene yang tidak baik yaitu 61 orang $(81,3 \%)$ dan sebagian kecil responden memiliki personal hygiene yang baik yaitu 14 orang (18,7\%). Berdasarkan sanitasi jamban, sebagian besar responden memiliki sanitasi jamban yang tidak memenuhi syarat yaitu 53 orang $(70,7 \%)$ dan sebagian kecil responden memiliki sanitasi jamban yang memenuhi syarat yaitu 22 orang $(29,3 \%)$. Berdasarkan sumber air, sebagian besar responden memiliki sumber air yang memenuhi syarat yaitu 46 orang $(61,3 \%)$ dan sebagian kecil responden memiliki sumber air yang tidak memenuhi syarat yaitu 14 orang $(38,7 \%)$. Berdasarkan kejadian diare pada balita, seluruh responden merupakan penderita diare yaitu 75 orang $(100 \%)$.

Tabel 1. Karakteristik Responden

\begin{tabular}{lcc}
\hline Variabel & Jumlah Sampel & Persentase \\
\hline Umur & 12 & \\
$1,0-1,4$ tahun & - & 16 \\
$1,5-1,9$ tahun & 22 & - \\
$2,0-2,4$ tahun & - & 29,3 \\
$2,5-2,9$ tahun & 20 & - \\
3,0-3,4 tahun & - & 26,7 \\
3,5-3,9 tahun & 21 & - \\
$\quad 4,0-4,4$ tahun & & 28 \\
Personal Hygiene & 14 & 18,7 \\
$\quad$ Baik & 61 & 81,3 \\
$\quad$ Tidak baik & & \\
Sanitasi Jamban & 22 & 29,3 \\
$\quad$ Memenuhi syarat & 53 & 70,7 \\
$\quad$ Tidak memenuhi syarat & & \\
Sumber Air & 46 & 61,3 \\
$\quad$ Memenuhi syarat & 29 & 38,7 \\
$\quad$ Tidak memenuhi syarat & & \\
Kejadian Diare & 75 & - \\
$\quad$ Mengalami diare & - & $\mathbf{1 0 0}$ \\
$\quad$ Tidak mengalami diare & $\mathbf{7 5}$ & \\
Total & &
\end{tabular}

Pada tabel 2 dapat dilihat bahwa dari 75 responden,yang memiliki personal hygiene baik dan mengalami diare yaitu 14 orang $(18,7 \%)$ dan responden yang memiliki personal hygiene yang tidak baik dan mengalami diare yaitu 61 orang ( $81,3 \%$.). Hasil uji chi square antara personal hygiene dengan kejadian diare pada balita diperoleh hasil $p=0,000(p<0,05)$ sehingga dapat disimpulkan bahwa ada hubungan antara personal hygiene dengan kejadian diare pada balita.

Penelitian Oloruntoba dkk. (2014) menunjukkan bahwa resiko diare yang terjadi di Nigeria terhadap anak balita secara signifikan lebih tinggi terjadi pada pada anak anak yang ibunya tidak mencuci tangan dengan sabun sebelum menyiapkan makanan. ${ }^{10}$ Penelitian yang dilakukan oleh Putra dkk. (2017) tentang menyimpulkan terdapat hubungan antara personal hygiene dengan kejadian diare pada balita di Wilayah Kerja Puskesmas Tasikmadu. ${ }^{11}$

Beberapa faktor lain yang menyebabkan terjadinya diare pada balita meskipun sudah memiliki personal hygiene yang baik adalah faktor sanitasi jamban dan sumber air yang tidak memenuhi syarat. Hal ini dibuktikan dengan hasil kuesioner di mana yang tidak memiliki sanitasi jamban yang baik dan sumber air yang 
memenuhi syarat cenderung memiliki sanitasi jamban yang buruk seperti berbau dan mudah dijamah serangga maupun tikus. Serangga dan tikus merupakan fektor pembawa kuman terhadap apa yang dihinggapinya, misalnya makanan dan minuman yang di konsumsi keluarga, maka keluarga akan mudah terkena diare. Dari hasil penelitian ini dapat dilihat bahwa keluarga yang memiliki personal hygiene yang tidak baik sebanyak 61 keluarga $(81,3 \%)$ yang juga merupakan penderita diare. Bakteri penyebab diare seperti e-coli dan staphyloccus biasanya masuk dalam tubuh melalui media makanan dan minuman. Dengan mencuci tangan usai beraktifitas dan sebelum makan, maka kemungkinan bakteri tersebut menginfeksi manusia semakin kecil. Cara mencuci tangan yang benar adalah menggunakan sabun. Tidak cuma telapak tangan yang dibasuh sabun, tetapi punggung tangan, sela-sela jari, dan juga selasela tangan. Karena kuman ternyata $60 \%$ berada di sela-sela jari, dan $40 \%$ di punggung tangan.

Tabel 2. Hasil uji chi square

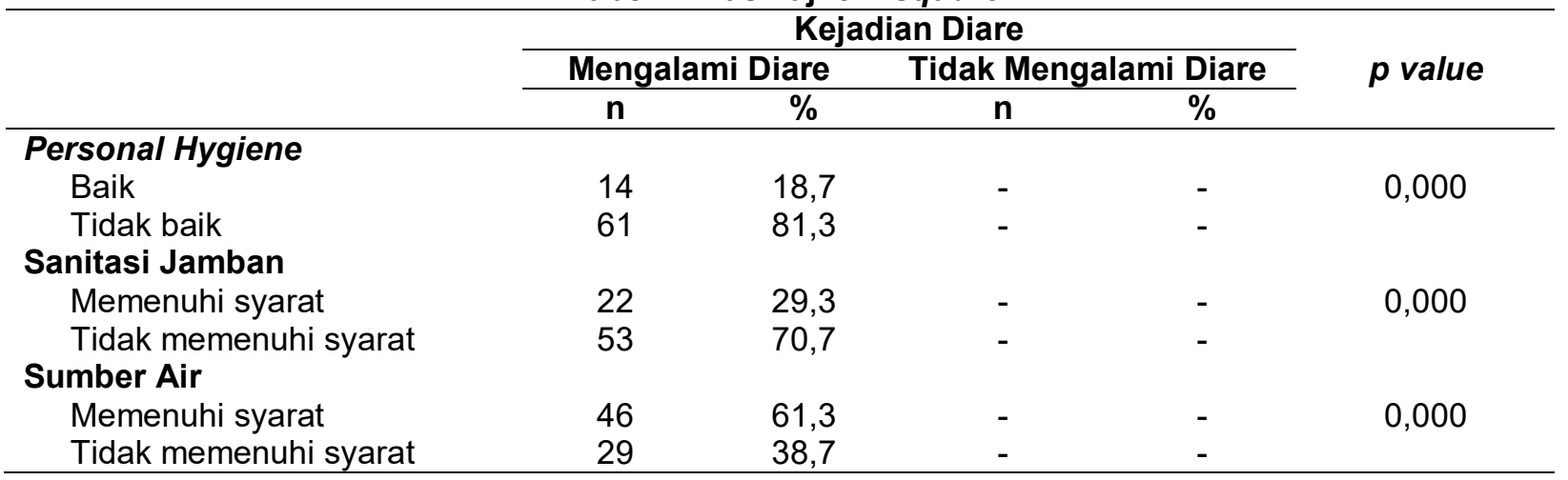

Dari penelitian ini dapat dilihat bahwa hygiene perorangan merupakan faktor yang sangat penting pada penyakit diare. Kejadian diare terjadi disebabkan karena personal hygiene yang dilakukan responden belum maksimal, kebanyakan responden yang melakukan kebiasaan mencuci tangan dengan sabun hanya saat setelah BAB selebihnya responden beranggapan bahwa mencuci tangan dengan air bersih saja sudah cukup. Responden masih memiliki kesadaran yang rendah untuk mencuci tangan dengan sabun, mereka hanya terbiasa mencuci tangan apabila tangan mereka terlihat kotor saja padahal tangan yang bersih belum tentu bebas dari kuman penyebab penyakit. Peralatan makan juga dapat menyebabkan diare di mana responden dalam meletakan tempat peralatan makan tidak di tempat yang memenuhi syarat yaitu diletakkan di luar rumah sehingga dapat tercemari oleh vektor seperti lalat dan lain sebagainya.

Dari 75 responden yang memiliki sanitasi jamban memenuhi syarat dan mengalami diare yaitu 22 orang $(29,3 \%)$ dan responden yang memiliki sanitasi jamban yang tidak memenuhi syarat dan mengalami diare yaitu 53 orang $(70,7 \%)$. Hasil uji chi square menunjukkan hasil $p=0,000 \quad(p<0,05)$ dan dapat disimpulkan bahwa ada hubungan antara sanitasi jamban dengan kejadian diare pada balita. Studi yang dilakukan oleh Setiyabudi dan Setyowati (2016) menunjukkan bahwa penggunaan jamban keluarga berhubungan dengan kejadian diare umur 15-50 tahun di wilayah Puskesmas Sokaraja. ${ }^{12}$

Penelitian Megersa dkk. (2019) yang dilakukan di Ethiopia terhadap anak anak umur di bawah lima tahun atau balita menunjukkan adanya diare karena kurang tersedianya fasilitas sanitasi khususnya jamban sehingga anak anak membuang air besar secara bebas sehingga menjadi factor terjadinya penyebaran bakteri yang akan mengakibatkan diare. ${ }^{13}$

Dari hasil penelitian ini dapat dilihat bahwa keluarga yang memiliki sanitasi jamban keluarga yang memenuhi syarat sebanyak 22 keluarga $(29,3 \%)$ merupakan penderita diare. Hal ini karena faktor lain yang mempengaruhi terjadinya kejadian diare pada balita. Terdapat responden yang memiliki sanitasi jamban yang tidak memenuhi syarat dan mengalami diare yaitu 53 orang $(70,7 \%)$. Akibat tidak memenuhi syarat sanitasi jamban dapat mengakibatkan timbulnya penyakit seperti diare dan infeksi dari cacing. Hal 
ini disebabkan oleh kandungan di dalam kotoran manusia/tinja mengandung banyak bakteri yang dapat menyebabkan penyakit seperti diare. Oleh karena itu perlunya masyarakat untuk memiliki sanitasi jamban yang memenuhi syarat agar tidak terjadinya lagi diare pada balita. Dari hasil kuesioner banyak masyarakat yang memiliki jamban yang mudah dijamah oleh serangga yang dapat menjadi vektor penyebab penyakit diare jika serangga tersebut hinggap di makanan keluarga. Di Kelurahan Bagan Deli, masyarakat mayoritas tidak memiliki atap pelindung jamban, dan jamban tidak mudah dibersihkan sehingga jamban tentunya akan sangat kotor yang kurang baik bagi kesehatan keluarga.

Selanjutnya dari 75 responden yang memiliki sumber air memenuhi syarat dan mengalami diare yaitu 46 orang $(61,3 \%)$ dan responden yang memiliki sumber air yang tidak memenuhi syarat dan mengalami diare yaitu 29 orang $(38,7 \%)$. Berdasarkan hasil uji chi square diperoleh hasil $p=0,000(p<0,05)$ sehingga dapat disimpulkan bahwa ada hubungan antara sumber air dengan kejadian diare pada balita. Penelitian yang dilakukan oleh Harsa (2019) menunjukkan terdapat hubungan antara sumber air dengan kejadian penyakit diare pada warga Kampung Baru Ngagelrejo Wonokromo Surabaya. ${ }^{14}$ Penelitian Cha dkk. (2015) yang dilakukan terhadap anak-anak dengan umur di bawah lima tahun yang berada di Ghana menunjukkan bahwa peningkatan pasokan air bersih dapat mengurangi diare pada anak balita hingga 11\% hal ini menunjukkan bahwa adanya keterkaitan sumber air terhadap terjadinya diare. ${ }^{15}$

Dari hasil penelitian ini dapat dilihat bahwa dari 75 responden, yang memiliki sumber air memenuhi syarat dan mengalami diare yaitu 46 orang $(61,3 \%)$. Hal ini dikarenakan dipengaruhi oleh faktor lain yaitu faktor personal hygiene yang tidak baik dan faktor sanitasi jamban yang tidak memenuhi syarat. Salah satu responden memiliki sumber air yang memenuhi syarat akan tetapi mengalami penyakit diare pada balita, hal ini disebabkan oleh faktor personal hygiene yang tidak baik dan sanitasi jamban yang tidak memenuhi syarat. Responden memiliki personal hygiene yang buruk seperti ibu tidak mencuci tangan setelah buang air besar, dan mencuci tangan sebelum memberi makan, dan anak tidak mencuci tangan setelah buang air besar yang berpengaruh terhadap balita yang menyebabkan terjadinya penyakit diare pada balita.

\section{KESIMPULAN}

Penelitian ini menyimpulkan bahwa personal hygiene $(p=0,000)$, sanitasi jamban $(p=0,000)$, dan sumber air berhubungan erat atau signifikan dengan kejadian diare pada balita di Kelurahan Bagan Deli Wilayah Kerja Puskesmas Belawan. Diharapkan kepada masyarakat agar memiliki kesadaran untuk menerapkan personal hygiene seperti kebiasaan mencuci tangan dengan sabun sebelum makan dan sesudah makan, kebiasaan mencuci tangan dengan sabun setelah buang air besar sehingga dapat mengurangi resiko terjadinya penyakit. Penting untuk membangun sumber air bersih dengan jarak $\geq 10$ meter dari sumber pencemar, membangun jamban yang sesuai dengan kriteria kesehatan, membangun saluran pembuang air limbah sesuai dengan kriteria kesehatan.

\section{REFERENSI}

1. Prajyaswari DAIS, Putri WCWS. 2018. Gambaran riwayat kejadian diare pada balita dan pelaksanaan PHBS dalam tatanan rumah tangga di Desa Gegelang Kecamatan Manggis tahun 2013. Intisari Sains Medis Vol.9 No. 1: 10-18

2. Kementerian Kesehatan RI. 2012. Profil Kesehatan Indonesia Tahun 2011. Pusat Data dan Informasi Kementerian Kesehatan. Jakarta.

3. Kementerian Kesehatan RI. 2019. Profil Kesehatan Indonesia Tahun 2018. Pusat Data dan Informasi Kementerian Kesehatan. Jakarta.

4. Dinas Kesehatan Provinsi Sumatera Utara. 2019. Profil Kesehatan Provinsi Sumatera Utara Tahun 2018. Kota Medan.

5. Notoatmodjo S. 2007. IImu Kesehatan Masyarakat: Prinsip-Prinsip Dasar. Rineka Cipta. Jakarta.

6. Nurpauji S, Nurjazuli N, Hanani DY. 2015. Hubungan Jenis Sumber Air, Kualitas Bakteriologis Air, Personal Hygiene Dengan Kejadian Diare Pada Balita di Wilayah Kerja Puskesmas Lamper Tengah Semarang. Jurnal Kesehatan Masyarakat Volume 3(1), pp. 569-578.

7. Sulaiman $R$, Wurangian I, Gunawan B. 2009. Panduan Masyarakat Untuk Kesehatan Lingkungan. The Eksyezet. Bandung.

8. Linda RE, Nugroho B, Andayani SRD. 2018. Hubungan Personal Hygiene Ibu dan Balita Dengan Kejadian Diare Pada Balita di Desa 
Bareng Kecamatan Bareng Kabupaten Jombang. Jurnal IImiah Kebidanan 4(1), 4551.

9. Wandansari AP. 2013. Kualitas Sumber Air Minum Dan Pemanfaatan Jamban Keluarga Dengan Kejadian Diare. KEMAS: Jurnal Kesehatan Masyarakat Vol 9 (1).

10. Oloruntoba EO, Folarin TB, Ayede Al. 2014. Hygiene and sanitation risk factors of diarrhoeal disease among under-five children in Ibadan, Nigeria. Afr Health Sci. 14(4):1001-11.

11. Putra ADP, Rahardjo M, Joko T.2017. Hubungan Sanitasi Dasar dan Personal Hygiene Dengan Kejadian Diare Pada Balita di Wilayah Kerja Puskesmas Tasikmadu Kabupaten Karanganyar. Jurnal Kesehatan Masyarakat Vol. 5 (1) pp. 422-429.

12. Setibudi R, Setyowati V. 2016. Penyediaan Air Bersih, Penggunaan Jamban Keluarga, Pengolahan Sampah, Sanitasi Makanan, Dan Kebiasaan Mencuci Tangan 16.
Umur 15-50 Tahun. MEDISAINS: Jurnal IImu-IImu Kesehatan Vol.14 (2)

13. Megersa S, Benti T, Sahiledengle B. 2019. Prevalence of Diarrhea and Its Associated Factors among Under-Five Children in Open Defecation Free and Non-Open Defecation Free Households in Goba District Southeast Ethiopia: A Comparative Cross-Sectional Study. Clinics in Mother and Child Health Vol 16 (3)

14. Harsa IMS. 2019. Hubungan Antara Sumber Air Dengan Kejadian Diare Padawarga Kampung Baru Ngagelrejo Wonokromo Surabaya. Journal of Agromedicine and Medical Sciences Vol 5 (3)

15. Cha S, Kang D, Tuffuor B, Lee G, Cho J, Chung J, Kim M, Lee H, Lee J, Oh C. 2015. The Effect of Improved Water Supply on Diarrhea Prevalence of Children under Five in the Volta Region of Ghana: A ClusterRandomized Controlled Trial. Int J Environ Res Public Health. Vol 12(10):12127-43. 